Revista Mídia e Cotidiano

Artigo Seção Temática

Volume 12, Número 2, agosto de 2018

Submetido em: 23/05/2018

Aprovado em: 29/05/2018

\title{
DO SLASHER AO FOUND FOOTAGE: AS TRANSFORMAÇÕES DO PONTO DE VISTA NO CINEMA DE HORROR
}

\section{FROM SLASHER TO FOUND FOOTAGE: SHIFTING PERSPECTIVES IN HORROR MOVIES}

\author{
Ana Maria ACKER ${ }^{1}$
}

\section{Resumo:}

$\mathrm{O}$ artigo discute as origens da câmera subjetiva diegética no cinema de horror found footage a partir do pressuposto de que tal estratégia narrativa possui relações com a câmera subjetiva do slasher, subgênero que gerou polêmica nas décadas de 1970 e 1980 . O texto problematiza o uso da câmera subjetiva e a transformação em diegética nos anos 2000, tendo como foco as características de nossos modos de olhar nas produções de horror contemporâneas. Pontuamos algumas mudanças no consumo do filme de horror como entretenimento após a metade do século passado e as relacionamos com as análises de sequências de três produções: As Fitas de Poughkeepsie (2007), direção de John Erick Dowdle; [Rec] (2007), realizado por Jaume Balagueró e Paco Plaza; e um episódio de V/H/S/2 (2013), filme de Simon Barrett, Adam Wingard, Eduardo Sanchez, Gregg Hale, Timo Tjahjanto, Gareth Huw Evans e Jason Eisener.

Palavras-chave: Cinema. Horror. Narrativa. Comunicação.

\begin{abstract}
:
The article discusses the origins of the subjective diegetic camera in the found footage horror film based on the assumption that such narrative strategy has relations with the subjective camera of the slasher, subgenre that caused controversy in the 1970s and 1980s. The text problematizes the use of subjective camera and the transformation to diegetic in the 2000s, focusing on the characteristics of our ways of looking in contemporary horror productions. We observe some changes in horror movie consumption as entertainment after the half of the last century. Beyond that, these ideas are related to three film reviews: The Poughkeepsie tapes (2007), directed by John Erick Dowdle; [Rec] (2007), shot by Jaume Balagueró and Paco Plaza; and on chapter of V/H/S/2 (2013), a film of Simon Barrett, Adam Wingard, Eduardo Sanchez, Gregg Hale, Timo Tjahjanto, Gareth Huw Evans and Jason Eisener.
\end{abstract}

Keywords: Cinema. Horror. Narrative. Communication.

\footnotetext{
1 Professora da Universidade Luterana do Brasil - ULBRA, Campus Canoas, RS. Doutora em Comunicação e Informação pela Universidade Federal do Rio Grande do Sul - UFRGS. E-mail: ana acker@yahoo.com.br.
} 
Introdução

O horror no cinema sempre apresentou múltiplas propostas estéticas e narrativas, mas na última década a expansão do falso found footage teve impacto em cinematografias do mundo inteiro, levantando questões acerca dos desdobramentos dessa proposta nas tradições do gênero. Esses filmes se caracterizam como falsos documentários, obras montadas a partir de material supostamente encontrado, uso de imagens de câmeras de vigilância, webcam e câmera diegética (HELLER-NICHOLAS, 2014). Franquias, como Atividade Paranormal, impulsionaram o mercado, gerando novas produções nesse estilo, que além das salas de cinema encontram a web como plataforma de circulação.

O presente artigo se volta, portanto, a um aspecto do found footage de horror que vem se desenrolando há bastante tempo: a câmera subjetiva diegética. $\mathrm{O}$ artefato no ponto de vista da personagem aparece nas tramas de maneira reiterada e possui relações com a câmera subjetiva do slasher ${ }^{2}$, subgênero que gerou polêmica nas décadas de 1970 e 1980. Tanto o found footage quanto o slasher significaram momentos de mudanças, questionamentos acerca do horror enquanto um produto de entretenimento da cultura de massa. Os modos de construção do olhar nessas duas tendências têm conexões e marcam hábitos de apelo ao público e consumo do gênero ao longo das últimas quatro décadas.

No cinema, os gêneros sofrem transformações, mas há códigos que não mudam. Dessa forma, por que é importante estudar esses filmes? Rick Altman observa que "[...] os filmes de Hollywood oferecem prazer genérico como alternativa a normas culturais. Esse prazer deriva de uma percepção de que as atividades que o produzem estão livres do controle que a cultura exerce e que o espectador sente no mundo real"' (ALTMAN, 2000, p. 212, tradução nossa ${ }^{3}$ ). O autor diz ainda que, desse modo, a relação com essas produções se aproxima das posturas de consumo em parques de diversões, carnavais e eventos esportivos. Existe a busca por sensações particulares na fruição com essas obras

\footnotetext{
2 Derivação da palavra slash - cortar, talhar. Essas produções podem ser definidas como: "tipo de filme muito barato, em geral produzido de forma independente e estrelado por atores jovens e desconhecidos, que narra uma série de assassinatos espetaculares em cenários isolados e, de preferência, interioranos" (CÁNEPA, 2008, p. 63).

${ }^{3}$ No original: "[...] las peliculas de Hollywood ofrecen placer genérico como alternativa a las normas culturales. Este placer deriva de una percepción de que las actividades que lo producen están libres del control que la cultura ejerce y que el espectador siente en el mundo real".
} 
genéricas e, longe de parecer algo simples, os filmes de gênero necessitam de investigações exaustivas acerca de suas estruturas narrativas, culturais e das experiências estéticas que suscitam em públicos diversos do mundo todo.

Segundo Ian Conrich, “o filme de horror é provavelmente o mais forte, flexível e bem-sucedido gênero dentro do cinema contemporâneo" (CONRICH, 2010, p. 1, tradução nossa ${ }^{4}$ ). $\mathrm{O}$ autor sustenta o argumento na diversidade de obras com essas características: de blockbusters, (A Múmia, 1999 - 2008), passando por sucessos independentes (O Sexto sentido, A Bruxa de Blair, ambos de 1999), a filmes para crianças e jovens (Coraline, 2009 e Crepúsculo, 2008) e lançamentos cult internacionais ( $O$ Labirinto do fauno, 2006). Além disso, há uma série de refilmagens, bem como adaptações de produções asiáticas, em especial as japonesas. Tal variedade de filmes refuta a ideia de que o gênero estaria esgotado.

Em tempos de queda na comercialização mundial de ingressos nas salas de cinema, o horror possui facilidade para se expandir em outras janelas de exibição, como cineclubes, festivais específicos, comercialização de DVDs e, claro, internet (CONRICH, 2010). Blogs, sites de fãs, grupos em redes sociais ampliam os debates e as conexões acerca das produções, o que antes dependia de revistas especializadas e fanzines, salienta Conrich (2010). O horror sempre manteve laços estreitos com a cultura popular, quadrinhos, literatura de bolso, e as transformações digitais das últimas décadas estimularam ainda mais o alcance desse gênero.

Diante dessas problemáticas, o texto discute o uso da câmera subjetiva e a transformação em diegética nos anos 2000, tendo como foco as características de olhar nas produções de horror contemporâneas. $\mathrm{O}$ artigo pontua algumas mudanças no consumo do filme de horror após a metade do século passado e as relaciona com as análises de excertos de três produções: As Fitas de Poughkeepsie (2007), direção de John Erick Dowdle; [Rec] (2007), dirigido por Jaume Balagueró e Paco Plaza; e um episódio de V/H/S/2 (2013), filme de Simon Barrett, Adam Wingard, Eduardo Sanchez, Gregg Hale, Timo Tjahjanto, Gareth Huw Evans e Jason Eisener.

\footnotetext{
${ }^{4}$ No original: "The horror film is arguably the most robust, pliable and successful of genres within contemporary cinema".
} 


\section{Do horror moderno ao slasher}

Nos anos 1960, as transformações do horror exacerbaram o pano de fundo realista, o que talvez tenha contribuído para o alargamento das temáticas. As adaptações dos clássicos da literatura, de monstros em castelos e épocas distantes, davam lugar a um horror mais urbano que levava o sobrenatural ou o medo da violência para as casas das famílias. Em meio à multiplicidade de realizações, há quem delimite algumas tendências do gênero, tendo como base as produções norte-americanas e europeias. Peter Hutchings (2004, p. 27) empreende uma categorização que nos ajuda a pensar determinadas recorrências temáticas e estilísticas ao longo dos anos, embora tenhamos que reconhecer que essas listas geralmente são arbitrárias:

1930 - Horror da Universal - Dracula, Frankenstein, A Múmia, etc.

1940 - Produções de Val Lewton na RKO - Sangue de Pantera (Cat People) 1942, A Morta-viva (I Walked with a Zombie) 1943, A Sétima vitima (The Seventh Victim) (1943), etc.

Segunda onda da Universal - O Lobisomem (The Wolf Man) 1941, A Casa de Frankenstein (House of Frankenstein) 1944, e vários filmes de Abbott e Costello.

Começo dos anos 1950 - Ficção científica norte-americana e horror - O Monstro da Lagoa Negra (Creature from the Black Lagoon) 1954, A Ameaça veio do espaço (It came from outer space) 1953, O Monstro do Ártico (The Thing from Another World) 1951.

Final dos anos 1950 - Horror britânico, especialmente filmes produzidos pela Hammer - A Maldição de Frankenstein (The Curse of Frankenstein) 1957, Dracula 1958, A Múmia (The Mummy) 1959, A Maldição do Lobisomem (The Curse of the Werewolf) 1961.

Pós-1968 - O moderno e contemporâneo horror dos Estados Unidos - O Bebê de Rosemary (Rosemary's Baby) 1968, A Noite dos Mortos Vivos (Night of the Living Dead) 1968, O Exorcista (The Exorcist) 1973, O Massacre da Serra Elétrica (The Texas Chainsaw Massacre) 1974, etc. 


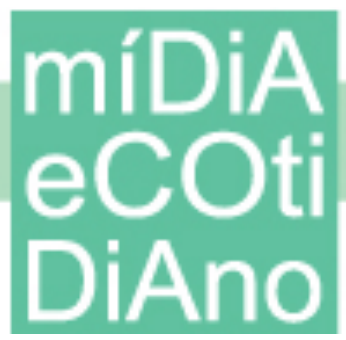

\section{PPGMC}

Pós-1978 - O filme slasher - Halloween, 1978 e a franquia Sexta-Feira 13 (Friday the 13th), iniciada em 1980.

A divisão de Hutchings deixa de fora diversos filmes produzidos no período e que não se encaixam nessas classificações. Apesar disso, mostra que há entre os críticos e pesquisadores um esforço de mapeamento de elementos estéticos e narrativos do gênero ao longo das décadas.

Figura 1 - A família em decadência em O Massacre da Serra Elétrica.

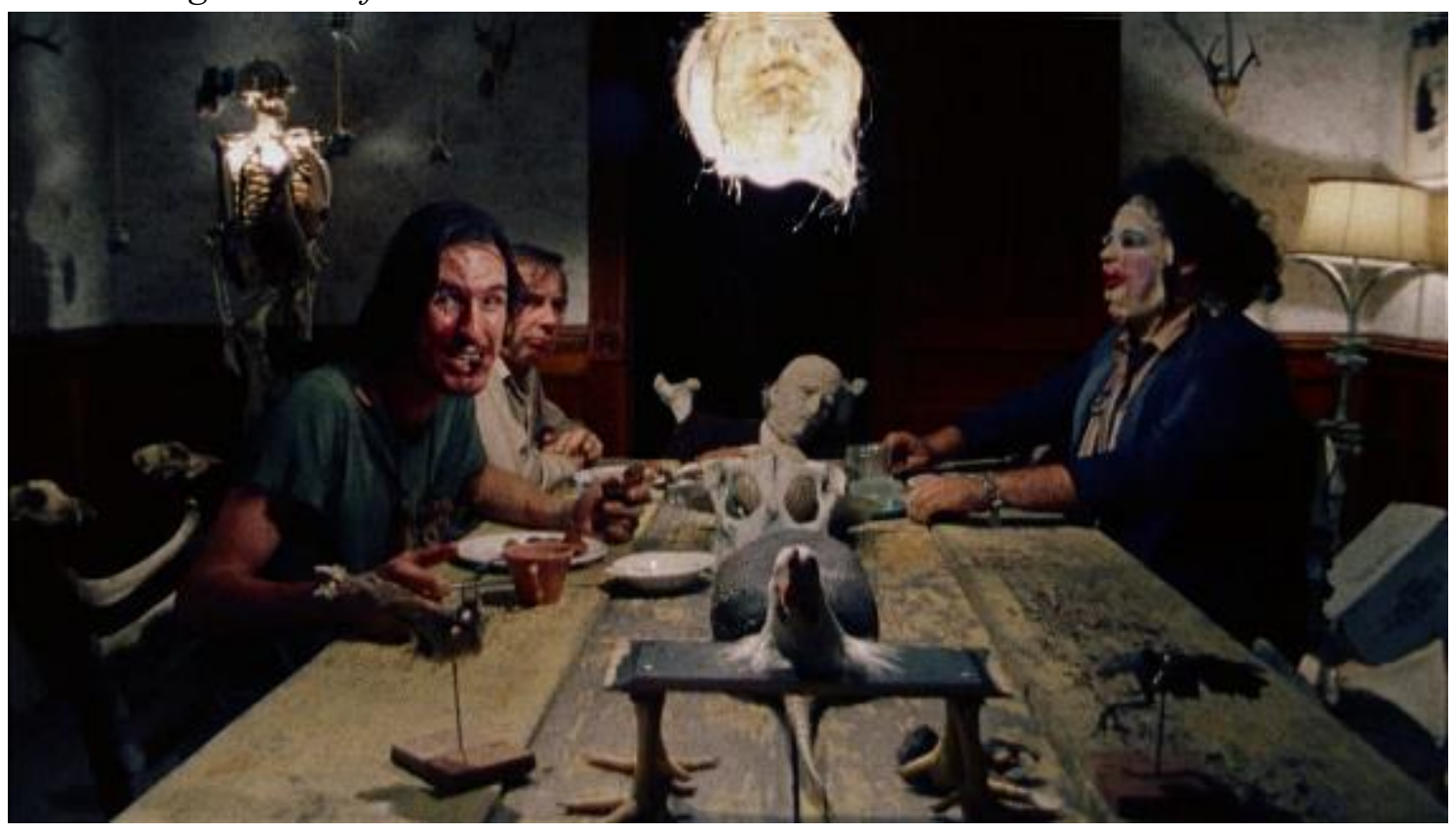

Fonte: Reprodução

Hutchings constata que a família no cinema, sobretudo no período da década de 1960 a 1980, simboliza um microcosmo da sociedade, que passava por profundas transformações culturais, comportamentais e políticas (2004, p. 183). Há certa ambivalência entre 1960 e 1970, como as diferenças das famílias de O Massacre da serra elétrica (1974) (Figura 1) e A Profecia (1976): enquanto que no primeiro a transgressão estética e narrativa é a ordem (proposta progressista); no segundo a manutenção do regime patriarcal e o estilo de horror clássico prevalecem (proposta reacionária) (WOOD, 1979). O Massacre da serra elétrica possui aspectos de amadorismo imagético e de experimentação sonora (CARREIRO, 2016) que de certa forma potencializam o horror e 
lançam uma semente para o que anos depois iria fundamentar o falso found footage de horror. Robin Wood ressalta outras particularidades da obra:

O sentido de horror do filme é intimamente ligado a uma sensação de fundamental absurdo. A família, afinal, só exerce a sua conclusão lógica do básico, embora não declarado, princípio do capitalismo, que as pessoas têm o direito de descartar os outros. Na arte do século XX, o senso de absurdo é sempre intimamente ligado ao desespero total (Beckett e Ionesco, por exemplo) $^{5}$ (WOOD, 2003, p. 84, tradução nossa).

A afirmação de Wood sobre O Massacre da Serra Elétrica demonstra o quanto as transformações no horror foram impactantes e levaram a uma tendência de produção que evocava uma desintegração da sociedade contemporânea. O outro, em última análise, era nós mesmos. Nesse período, ocorre um deslocamento do monstro, que muitas vezes se manifesta em uma face oculta de pessoas comuns, como acontece em Carrie - a estranha (1976), de Brian De Palma (HUTCHINGS, 2004).

Esses tópicos de transgressão já aparecem em 1968 em A Noite dos mortos vivos, de George Romero, produção em que várias convenções de gênero são quebradas, como salienta Wood (2003): morte dos heróis, assassinato dos pais pela criança transformada em zumbi, entre outras. Psicose (1960), de Alfred Hitchcock, mescla elementos do gótico com o moderno (HUTCHINGS, 2004) e espanta pela violência do assassinato da protagonista (Figura 2). Para Hutchings (2004), a guinada por mais sangue e ousadia do horror teve início ainda nos anos 1950, com a produtora britânica Hammer e os filmes de outros diretores europeus, como o italiano Mario Bava e o francês Georges Franju. Para os realizadores, o foco em uma estética do choque tornou-se rentável.

A relação do horror com a cultura popular é enfatizada por diversos pesquisadores (CARROLL, 1999; CÁNEPA, 2008, CARREIRO, 2014); assim como a conexão com os temores do cotidiano, entre eles os avanços da tecnologia (FELINTO, 2008), questão que

\footnotetext{
${ }^{5}$ No original: "The film's sense of fundamental horror is closely allied to a sense of the fundamentally absurd. The family, after all, only carries to its logical conclusion the basic, though unstated, tenet of capitalism, that people have the right to live off other people. In twentieth-century art, the sense of the absurd is always closely linked to total despair (Beckett and lonesco, for instance)".
} 
é aprofundada a seguir. Todavia, esses estudiosos e outros reconhecem que o gênero se insere em rupturas, algumas delas apontadas acima na divisão de Hutchings.

O horror moderno conecta-se ainda com o cinema moderno propriamente dito, tanto nas experimentações narrativas, personagens ambíguos, errantes, tramas complexas; quanto nas estéticas, opacidade, montagem fragmentada, etc. Chocar é uma tradição dessas produções, contudo a partir do horror moderno esse objetivo atingiu outro estágio:

[...] no final dos anos 1950 e começo dos 1960, em grande parte como resposta às novas condições de mercado, esses elementos chocantes tornaram-se não apenas mais gráficos, mas também mais provocadores e indiscretos. Na realidade, eles funcionavam como performances ou atrações em benefício próprio, em parte, fortemente caracterizadas na forma como esses filmes foram comercializados (HUTCHINGS, 2004, p. 174 , tradução nossa $)^{6}$.

Temas como incesto, necrofilia e canibalismo não eram apenas extravagância, e sim estratégia mercadológica. $\mathrm{O}$ apelo às sensações dúbias do público mobilizava a crítica, que em sua maioria no final da década de 1950 via o horror como um tipo de produção cinematográfica de degradação cultural (HUTCHINGS, 2004). Por exemplo, quando do lançamento de A Maldição de Frankenstein (1957), da britânica Hammer, um artigo do Tribune disparou: "Para todos os amantes do cinema apenas duas palavras descrevem esse filme - Deprimente, degradante" (HUTCHINGS, 2004, p. 85, tradução nossa $)^{7}$. Havia ainda uma preocupação com o desenvolvimento das audiências mais jovens, crianças e adolescentes, em contato com essas produções.

O clima de desconfiança de parte da crítica e do público nunca foram empecilho para o desenvolvimento do gênero e, mesmo que as transformações mais significativas tenham se iniciado no final dos anos 1950, foi na década de 1970 que esse tipo de filme atingiu uma espécie de "era de ouro" com "maturidade e integridade artística assim como

\footnotetext{
${ }^{6}$ No original: [...] but in the late 1950 s, largely as a response to new market conditions, these shocking elements became not only more graphic but also more provocative and obtrusive. In effect they functioned as spectacles or attractions in their own right and, part of this, featured heavily in the way in which the films in question were marketed.

${ }^{7}$ No original: For all lovers of the cinema only two words describe this film - Depressing, degrading.
} 


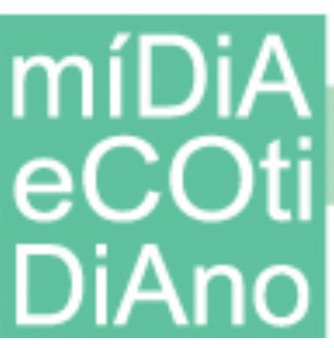

um senso de responsabilidade social" (HUTCHINGS, 2004, p. 170). Ou seja, as mudanças no cinema norte-americano como um todo, influenciadas pela contracultura, movimento hippie, manifestações contra a Guerra do Vietnã, onde a intervenção norteamericana durou de 1964 a 1975, deixaram marcas nas obras voltadas ao medo (BISKIND, 2009).

Figura 2 - Assassinato violento de Marion (Janet Leigh) chocou nos anos 1960.

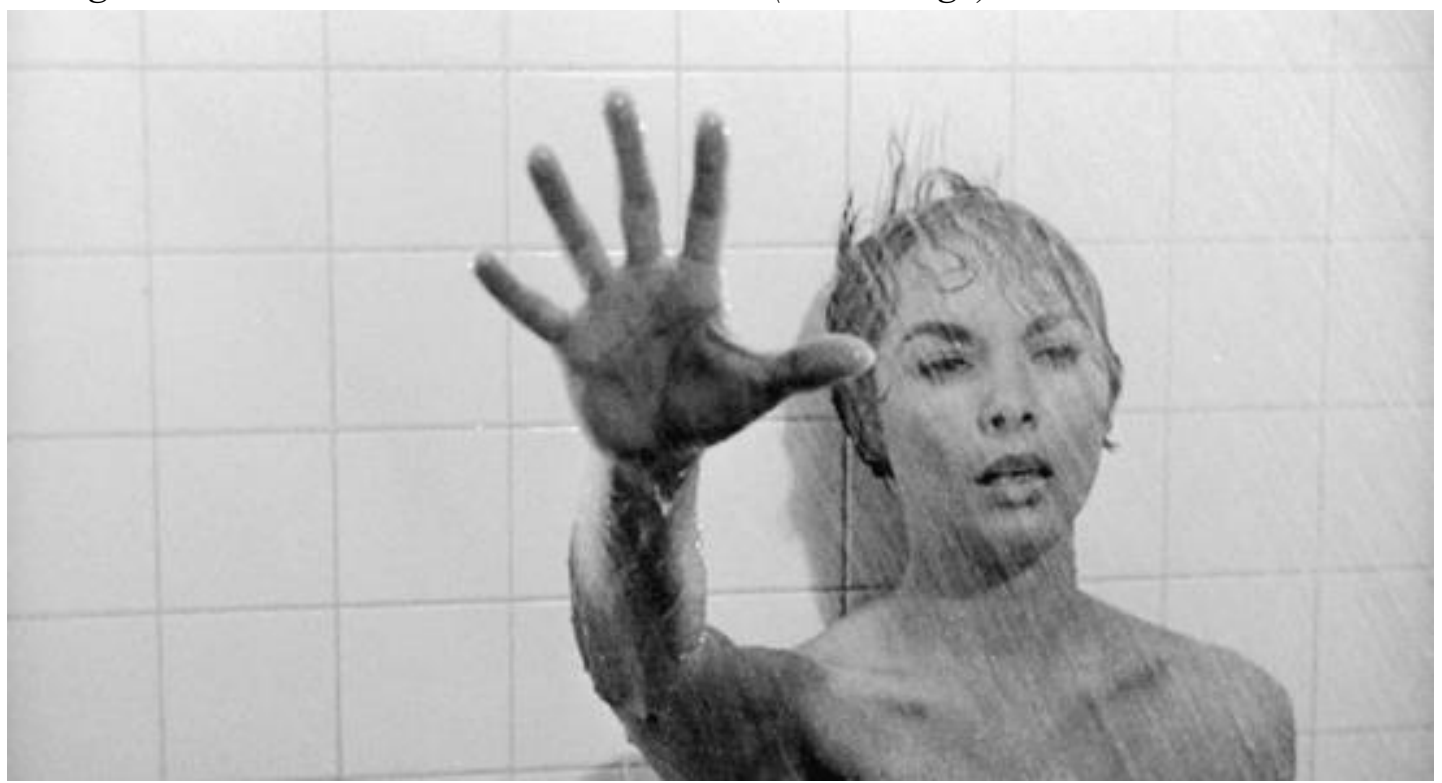

Fonte: Reprodução

A "era de ouro" do horror não significou uma unidade de produções - enquanto algumas atraíam público e crítica e buscavam polemizar; outras seguiam uma linha cautelosa, devedora do horror clássico. Essas distinções ficam evidentes na comparação entre películas como A Profecia e O Massacre da Serra Elétrica, já abordadas aqui. Segundo Wood, a onda de obras reacionárias se ampliou a partir dos anos 1980 e percebese, sim, uma relação entre a situação política do país, que contava com Ronald Reagan na presidência, e o que se via nas telas (WOOD, 2003). Conforme Biskind (2009), a era Reagan teve impacto na indústria audiovisual, expandindo uma tendência menos transgressora nas realizações.

Há características que são recorrentes nos chamados filmes reacionários de horror, de acordo com Wood (2003): 
1. A designação do monstro como algo mau. Mesmo sendo fruto da cultura, o aspecto ruim predomina nas criaturas: “o que é reprimido (no indivíduo, na cultura) deve sempre voltar como uma ameaça, percebida pela consciência como algo feio, terrível, obsceno" (WOOD, p. 170, 2003, tradução nossa ${ }^{8}$ ). Os monstros são, em sua maioria, destrutivos, e tal comportamento pode ser explicado e, às vezes, justificado;

2. A presença do Cristianismo de maneira contundente nos filmes de Hollywood;

3. A apresentação do monstro como totalmente não humano. As produções de ficção científica dos anos 1950, de larga crítica ao comunismo da União Soviética, traziam esse aspecto referente às criaturas ameaçadoras;

4. Relação confusa e ambígua com a sexualidade, que geralmente aparece de forma negativa ou tabu. Podemos identificar casos de punição do monstro em função de atitudes sexuais que afrontavam as regras conservadoras (ex: jovem casal surpreendido por alguma criatura durante o ato sexual - algo que se tornou clichê).

Em contraposição a essa tendência, estão os filmes de horror apocalípticos, carregados de pessimismo e em uma crença da ruína do capitalismo patriarcal (WOOD, 2003). Wood argumenta que essas características não são estanques, mas é difícil que uma obra seja realizada imune a algumas delas.

Outro comentário sobre essas produções do período é em função da violência contra a mulher, como se a morte de garotas e a exposição de seus corpos fosse um modo de crítica ao feminismo em ascensão (WOOD, 2003). Por outro lado, a questão é complexa e os pesquisadores divergem. Conforme Hutchings (2004), é, sobretudo a partir do livro de Carol Clover, Men, Women and Chainsaws (1992), que podemos perceber nuances nos filmes slasher no que diz respeito à representação da mulher, podendo ser identificados traços progressistas nas heroínas (como a figura da last girl, a última sobrevivente que geralmente derrota o monstro).

\footnotetext{
${ }^{8}$ No original: "what is repressed (in the individual, in the culture) must always return as a threat, perceived by the consciousness as ugly, terrible, obscene".
} 


\section{A CRISTALIZAÇÃO DA CÂMERA SUBJETIVA NO HORROR}

É no final dos anos 1970 e começo dos 1980 que se amplia a exploração do point of view (ponto de vista) do monstro ou do serial killer. As sequências de abertura de Halloween (1978) e Sexta-Feira 13 (1980) apresentam essas escolhas narrativas, que são perceptíveis pela instabilidade da câmera, indicando a movimentação da ameaça em direção às vítimas (HUTCHINGS, 2004): “[...] o significado do uso do ponto de vista está longe de ser claro. Uma abordagem influente é argumentar que tal técnica incentiva o público a se identificar com o assassino e, assim, ganhar um prazer sádico dele (ou, mais raramente, dela)" (HUTCHINGS, 2004, p. 195, tradução nossa) ${ }^{9}$. Hutchings (2004), no entanto, refuta essa ideia, salientando que colocar o público no ponto de vista do assassino não significa uma aproximação com esse ou o apelo a um prazer sádico, uma vez que a estratégia pode enfatizar sim uma comoção pelos personagens. Há um incremento do suspense, da ansiedade diante do descompasso entre o que o espectador sabe a respeito da vítima, que ignora a situação de perigo em que se encontra. A noção de espaço ou orientação se desestabiliza e Hutchings enxerga mais estratégias narrativas próprias do gênero enfatizadas por esse recurso.

Figura 3 - Ponto de vista do então menino Michael Myers no começo de Halloween.

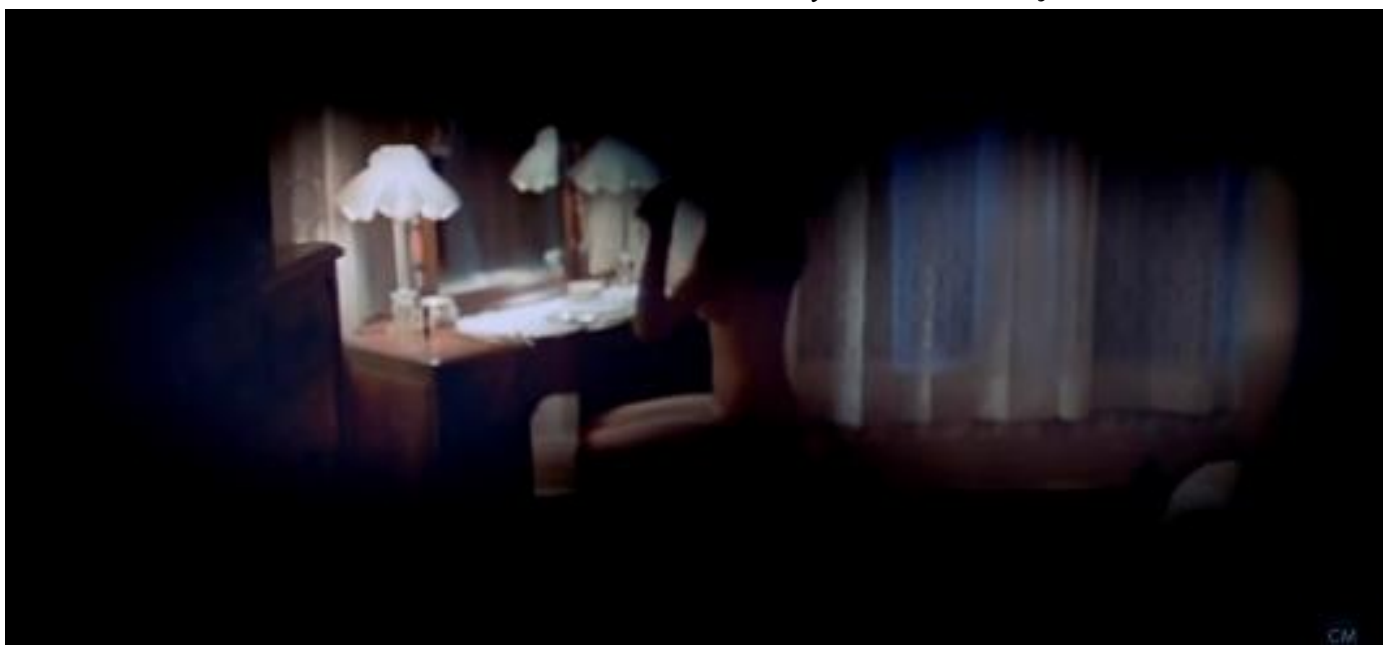

\footnotetext{
${ }^{9}$ No original: "[...] the significance of this use point of view is far from clear. One influential approach is to argue that such a technique encourages an audience to identify with the killer and thereby gain a sadistic pleasure from his (or, less commonly, her) murderous acts".
} 
Fonte: Reprodução

$\mathrm{Na}$ longa sequência de abertura de Halloween, por exemplo, o ponto de vista do então menino Michael Myers (Figura 3) conduz o olhar do espectador. É possível perceber uma conexão direta com a exploração do ponto de vista na câmera subjetiva diegética hoje nos filmes de horror found footage, o que reforça as origens do recurso narrativo bastante utilizado nas produções contemporâneas.

Em Prelúdio para Matar (1975), de Dario Argento, no começo do filme há uma sequência em que o público 'passeia' por um auditório pela visão do assassino (Figura 4). O recurso da câmera subjetiva foi amplamente explorado, tornando-se praticamente um clichê do gênero. Em 1981, Sam Raimi exacerbou a estratégia dramática ao colocála no ponto de vista do espírito maligno em A Morte do Demônio, pois chama a atenção a rapidez do deslocamento do olhar pela floresta em perseguição aos jovens acuados na cabana. Aliás, a produção se encerra dessa forma (Figura 5), com o demônio indo em direção a Ash (Bruce Campbell), o último personagem vivo.

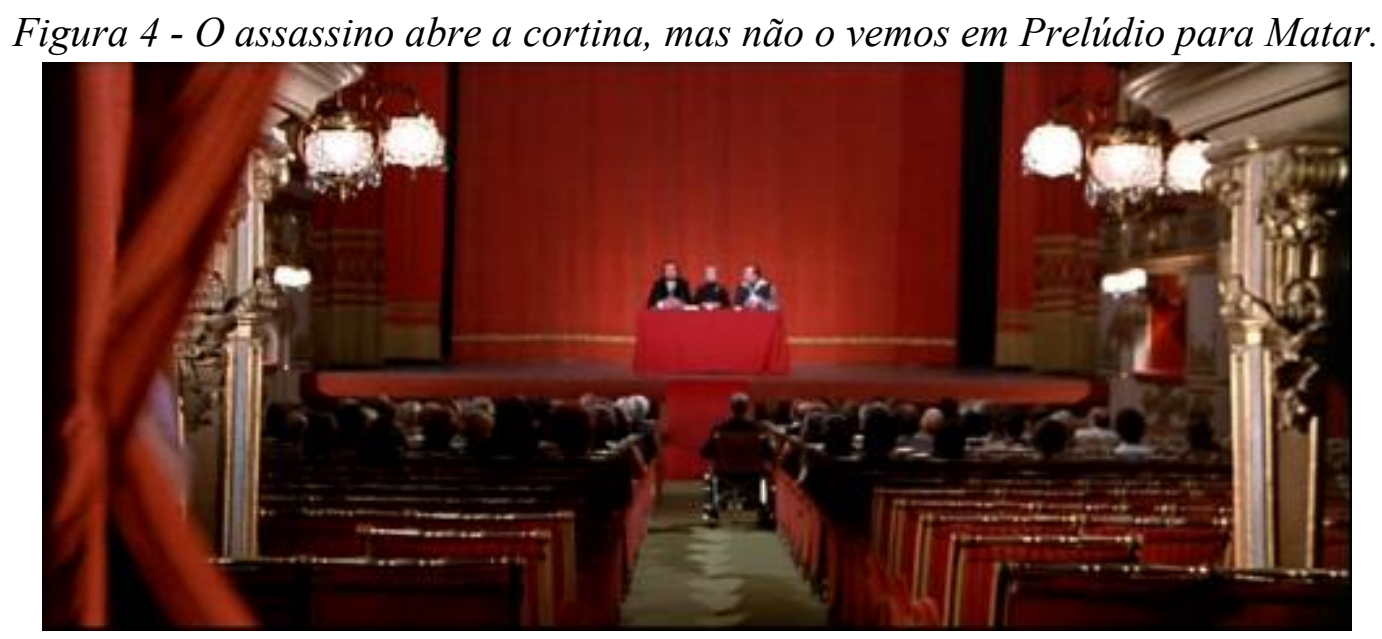

Fonte: Reprodução

Em O Predador (1987), de John McTiernan, a câmera subjetiva na criatura revela como a mesma enxerga os humanos - algo que se assemelha aos artefatos que registram o calor (Figura 6). Três anos antes, a ficção científica $O$ Exterminador do futuro, de James 
Cameron, do mesmo modo explorou o ponto de vista do ciborgue interpretado por Arnold Schwarzenegger. O recurso tornou-se uma marca de ambas as produções, aparecendo ainda em sequências.

Há, desse modo, transformações no horror dos anos 1960, 1970 e 1980 que influenciaram os mecanismos narrativos das produções recentes. É necessário citar que nas décadas de 1980 e 1990 houve um crescimento expressivo de sequências e franquias com o intuito de prolongar a permanência de personagens de sucesso nas telas, como o Jason de Sexta-feira 13 ou Freddy Krueger, de A Hora do pesadelo (HUTCHINGS, 2004). Em vários casos, a fórmula tornou-se repetitiva e podemos citar Pânico (1996), de Wes Craven, como um pós-slasher que de certa forma revitaliza o gênero, especialmente com referências a produções consagradas (HUTCHINGS, 2004).

Figura 5 - Sequência final de A Morte do Demônio.

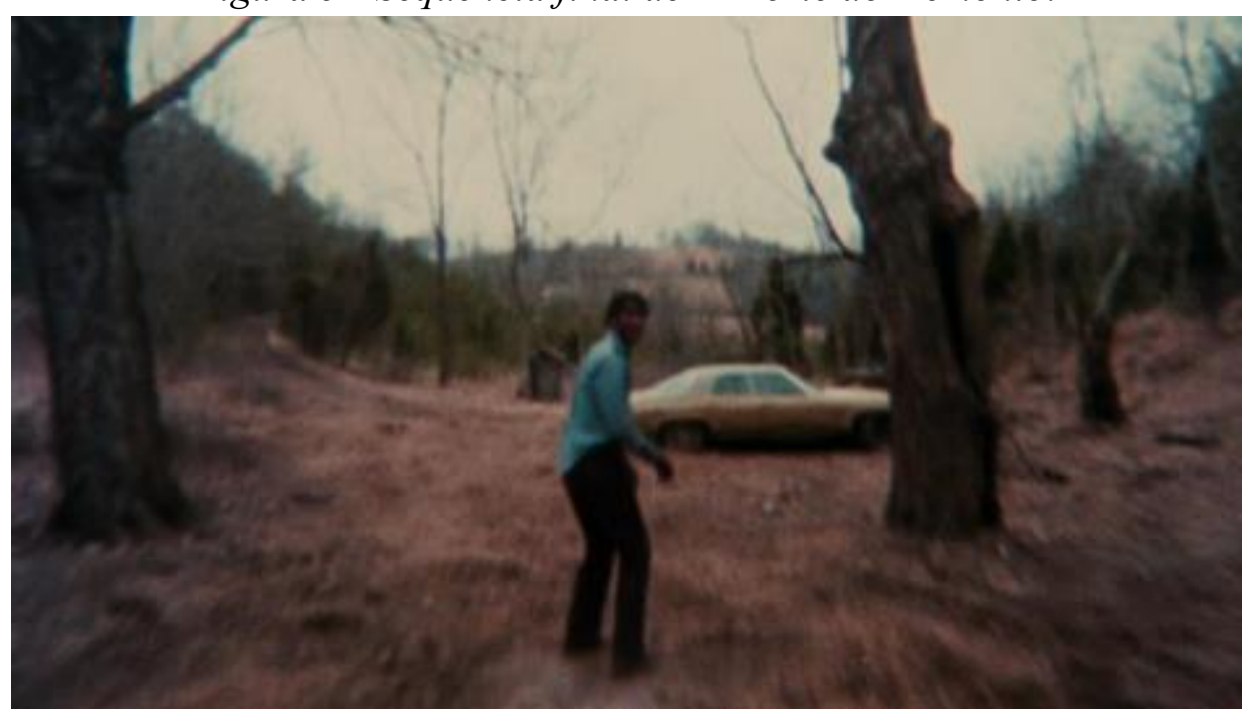

Fonte: Reprodução

Figura 6 - Plano subjetivo do monstro em O Predador. 


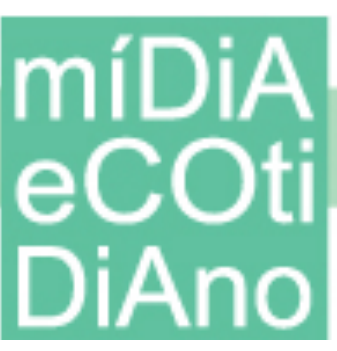

\section{PPGMC}

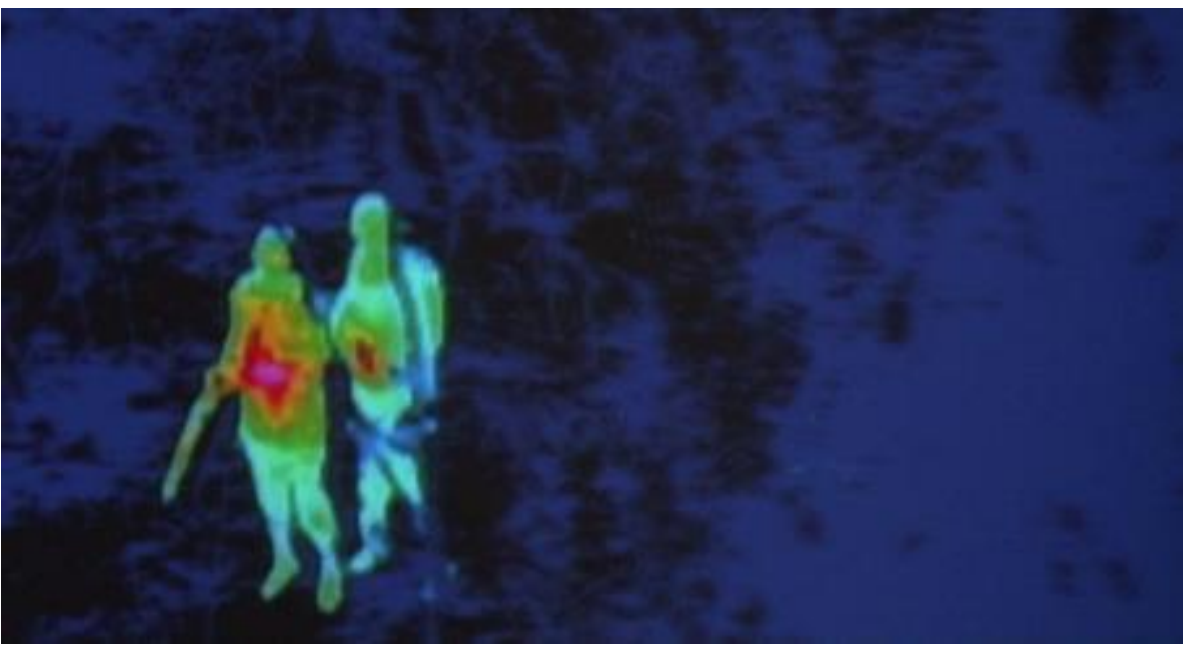

Fonte: Reprodução

A câmera subjetiva diegética é talvez o recurso narrativo que melhor identifica os filmes de horror found footage. Se no slasher o ponto de vista era o do monstro ou do ser ameaçador; hoje, ele se desloca, sobretudo, para o foco da vítima. Segundo Edward Branigan (2005), o "plano-ponto-de-vista" (PPV) é um plano em que a câmera assume a posição de um sujeito de modo a nos mostrar o que ele está vendo" (p. 251). O autor destaca que, além de pessoas, essa proposta é usada em animais, coisas e até mortos, como ocorre nos belos planos de Vampyr (1932) (Figura 7), de Carl Dreyer.

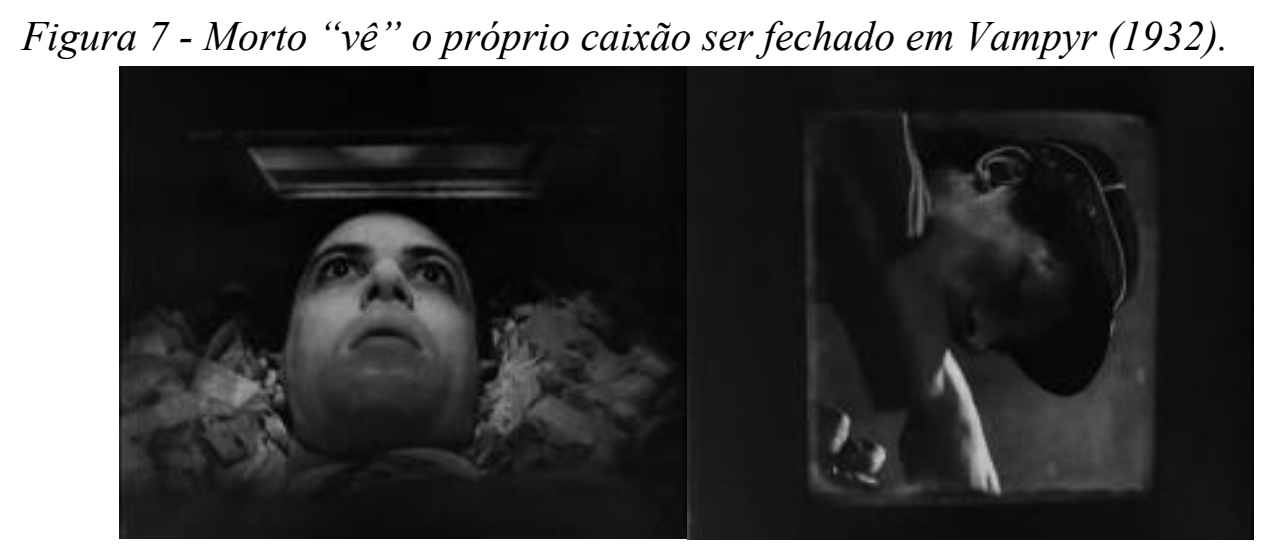

Fonte: Reprodução

Conforme Carreiro, o ponto de vista varia nas obras de horror contemporâneo, embora haja um elemento que se mantenha constante: 
A posição do observador pode variar (em alguns filmes o ponto de vista é da vítima; em outros, de uma testemunha; há casos em que o registro é providenciado pelo agressor, e filmes em que o ponto de vista transita entre as três opções anteriores), mas algo nunca varia: o dispositivo de registro (a câmera, o computador, o celular, o gravador de sons) sempre faz parte da diegese, do universo fílmico. Os personagens têm consciência desse dispositivo e se envolvem com ele (CARREIRO, 2016, p. 124).

A câmera é sempre diegética nessas produções, entretanto nem sempre subjetiva. Há alterações na exploração desses olhares, como podemos observar nas análises dos filmes.

\section{A CÂMERA SUBJETIVA DIEGÉTICA NO HORROR FOUND}

\section{FOOTAGE}

Se nas questões temáticas as produções recentes mantêm conexão com as tradições do horror; em termos estéticos e narrativos a ligação com o slasher e o horror moderno se dá com algumas variações. Em As Fitas de Poughkeepsie ocorre o uso da câmera subjetiva diegética pelo assassino em série. A exploração lembra a do slasher, contudo nos filmes das décadas de 1970 e 1980 percebia-se, geralmente, um distanciamento do agressor em relação às vítimas, o que não ocorre aqui. $\mathrm{O}$ assassino fala com as pessoas, está próximo, pode agir a qualquer momento. Os movimentos bruscos e as falhas na imagem amplificam a sensação de ameaça, uma vez que o uso desse recurso narrativo se estabelece em momentos diversos do filme.

Em um deles, dos 06min39s a 09min19s, o serial killer se aproxima de uma garotinha após passar de carro em frente à casa dela. À medida que ele chega perto da menina e tenta conversar, a imagem se distorce. Ele elogia as bonecas, mas a pequena afirma não poder falar com estranhos.

Figura 8 - Assassino se aproxima de criança brincando no pátio. 

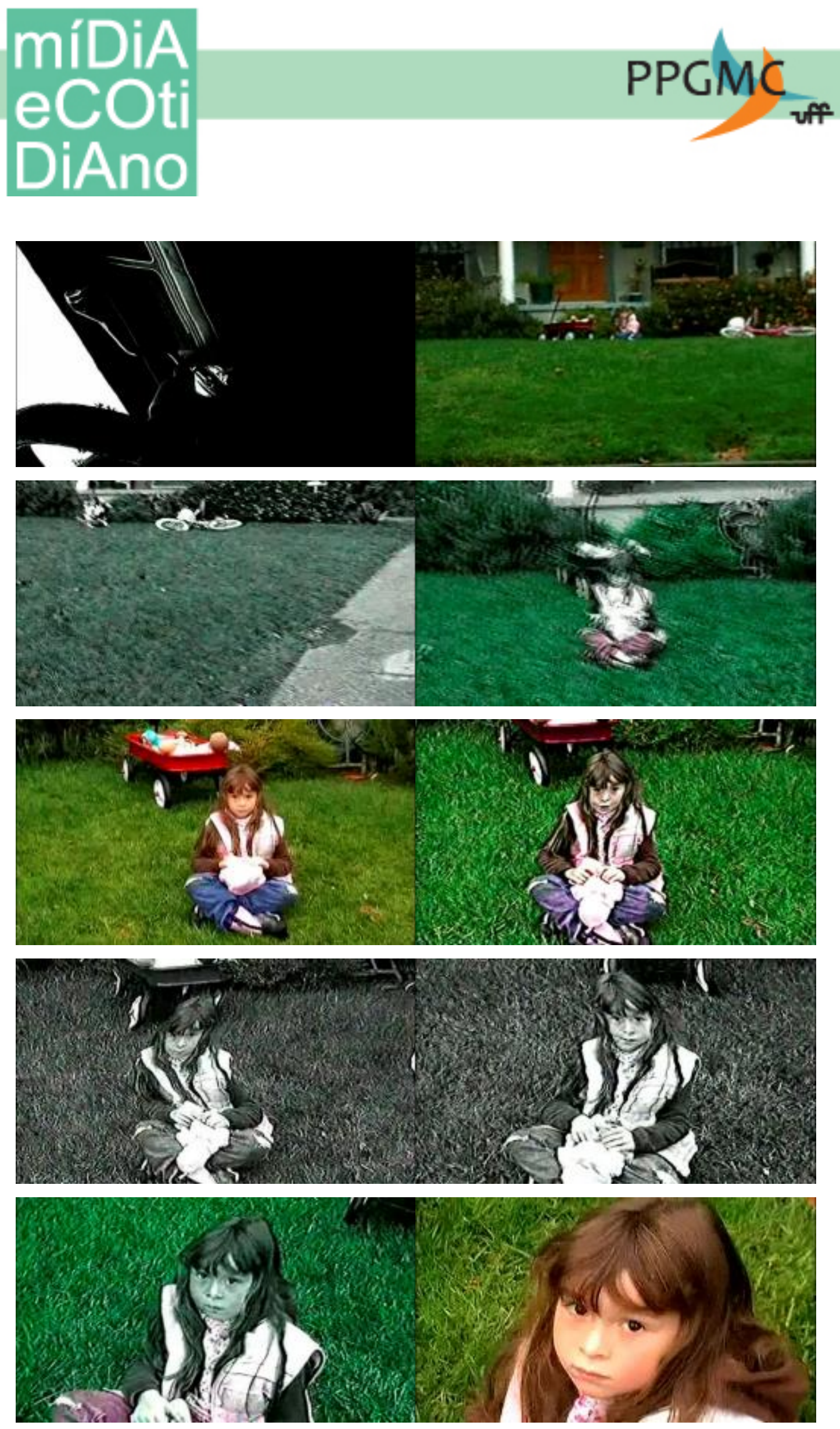

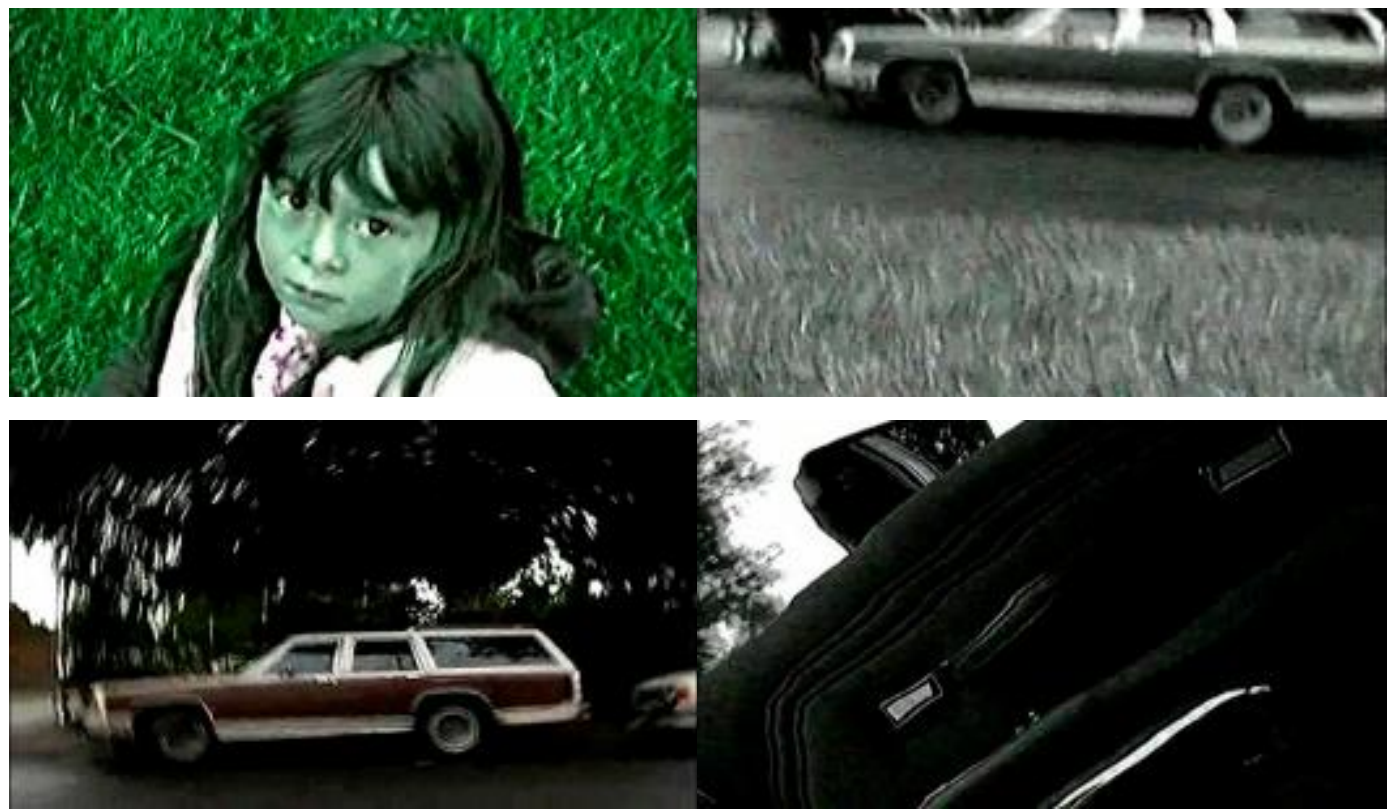

Fonte: Reprodução

O plano geral da chegada situa a casa da criança, o ambiente (Figura 8). Durante a aproximação, o enquadramento se torna um primeiro plano dela, cada vez mais assustada (Figura 8). O plongée confirma o aumento do medo em relação àquela presença estranha. A pequena é lacônica, irrita o assassino, que acaba cometendo o crime no local. O ato não é mostrado ao espectador, que obtém a informação pelo gesto brusco com a câmera e os sons emitidos pelo homem. Não há qualquer barulho de grito da vítima. Depois do crime, o assassino corre para o carro, ainda segurando a câmera (final da Figura $8)$.

É pertinente compreender que o uso da câmera subjetiva diegética se dá de diversas formas nas obras pesquisadas, só que uma questão fica: como ocorre o processo de identificação com as personagens nas produções que usam tal conduta narrativa? Essa discussão é profícua nos estudos de cinema de horror, principalmente no impasse envolvendo o slasher. Segundo Nick Browne, o processo de identificação leva o espectador a estar com a câmera e "com" a pessoa representada:

Encontra-se aí sua dupla estrutura, definida como aquele que vê/é visto. Trata-se de um forte processo emocional que coloca em questão qualquer explicação da posição do espectador centralizado em um único 
ponto ou no centro de um sistema simplesmente óptico (BROWNE, 2005. p. 240).

Porém, no found footage de horror, em muitas situações, o foco de identificação não aparece na tela, quando a personagem que filma se manifesta apenas pela voz. Isso pode significar um obstáculo para o processo, mas é preciso levar em conta o desenrolar da narrativa, como essa personagem cinegrafista se coloca na trama:

Evidentemente, o espectador está em vários lugares ao mesmo tempo: com aquele que vê no interior da ficção, com aquele que é visto, e, ao mesmo tempo, em posição para avaliar e responder aos argumentos de cada um deles. Isso indica que, tal como aquele que sonha, o espectador fílmico é um sujeito plural: em sua leitura, ele é e não é ele mesmo (BROWNE, 2005, p. 246).

Portanto, isso quer dizer que se o ponto de vista na tela é o do monstro, assassino em série ou espírito não significa que o público vá se aliar a eles. $\mathrm{Na}$ análise do trecho de As Fitas de Poughkeepsie nos identificamos com a menina, ser olhado, assim como ocorre com a personagem Dallas de Nos tempos das diligências (1939), de John Ford, em sequência investigada por Browne (2005).

Já em [Rec] a preponderância da câmera em primeira pessoa é expandida. “Aconteça o que acontecer, nunca pare de gravar". A frase que está na capa do DVD do filme dá um indício da trama. A repórter Ángela Vidal (Manuela Velasco) é acompanhada pelo cinegrafista Pablo (Pablo Rosso), que não aparece e é quem direciona o olhar com as imagens que manipula através dos enquadramentos, comentários e impressões da situação no edifício atacado por um vírus que transforma os habitantes em estranhas criaturas.

A presença da câmera é questionada por moradores, autoridades, e os próprios bombeiros. O cinegrafista e a repórter chegam a afirmar que a mesma está desligada, mas seguem registrando os fatos. Essa aversão é comum no found footage e já aparece em Canibal Holocausto (1980), de Ruggero Deodato.

Há que se destacar a constância de planos-sequência em [Rec] (e no found footage em geral) e a forma como são realizados. Se a aparência de amadorismo está em diversas 
produções, aqui o fato do cinegrafista ser de televisão é o mote para os diretores imprimirem um tom "profissional" no registro das imagens e na articulação de como pensar rápido no acompanhamento das ações.

No Dicionário teórico e crítico de cinema, Jacques Aumont e Michel Marie afirmam que:

Para a reflexão teórica, especialmente sobre a montagem, o planosequência sempre foi um objeto incômodo; ele obriga admitir que pode haver montagem no interior de um plano (Eisenstein, Mitry) e coloca sérios problemas a qualquer modelo de segmentação dos filmes, como mostram as dificuldades da grande sintagmática da banda imagem (Metz) sobre esse assunto.

Do ponto de vista estético, ele foi defendido (a propósito de Welles e Wyler) por André Bazin, que via nele, junto com a profundidade de campo, um instrumento de realismo, que permitia evitar a fragmentação do real, e respeitava, portanto, a um só tempo, o próprio real e a liberdade do espectador. Vários autores (Mitry, Comolli) frisaram que essa concepção do realismo era apenas uma possibilidade entre outras, e que, aliás, o plano sequência não era tão "realista" e "transparente" quanto Bazin havia acreditado, que seu valor dependia das normas estéticas em vigor (AUMONT; MARIE, 2003, p. 231)

O uso do plano-sequência na película espanhola evidencia justamente o alerta de Mitry e Comolli: nem sempre esse recurso garante transparência narrativa. De 08:44 a 14:00 e de 14:01 a 18:43 temos dois planos-sequência que apresentam a entrada dos bombeiros e da equipe de tevê no prédio. A ação se desenrola até o ataque da primeira mulher zumbi ao policial e a mobilização de todos pelo salvamento do homem. Nos trechos, temos apenas os cortes assinalados acima e a mise-en-scène é frenética justamente pelos movimentos de câmera e lente efetuados por Pablo.

Alguns momentos dos dois excertos podem ser evidenciados como tentativas em contar mais ao espectador para além do ângulo de visão do cinegrafista. Como há uma transmissão para a televisão, isso se justifica no roteiro. Logo na entrada ao edifício, acompanhando a correria dos bombeiros, há um plano geral do ambiente, situando o local, apresentando as pessoas envolvidas, colocando o público a par do conflito existente. 


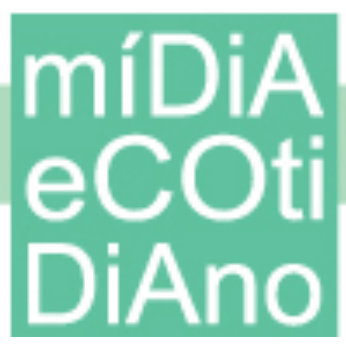

\section{PPGMC}

Em seguida, Pablo passa pelo policial que desce as escadas e se posiciona atrás deste, apresentando outro plano geral. Não há cortes bruscos, o plano reordena a ação (Figura 9) para a subida das escadas e verificação do que se passa no andar superior.

Figura 9 - Plano geral situa o espectador na ação. Repórter orienta o cinegrafista.

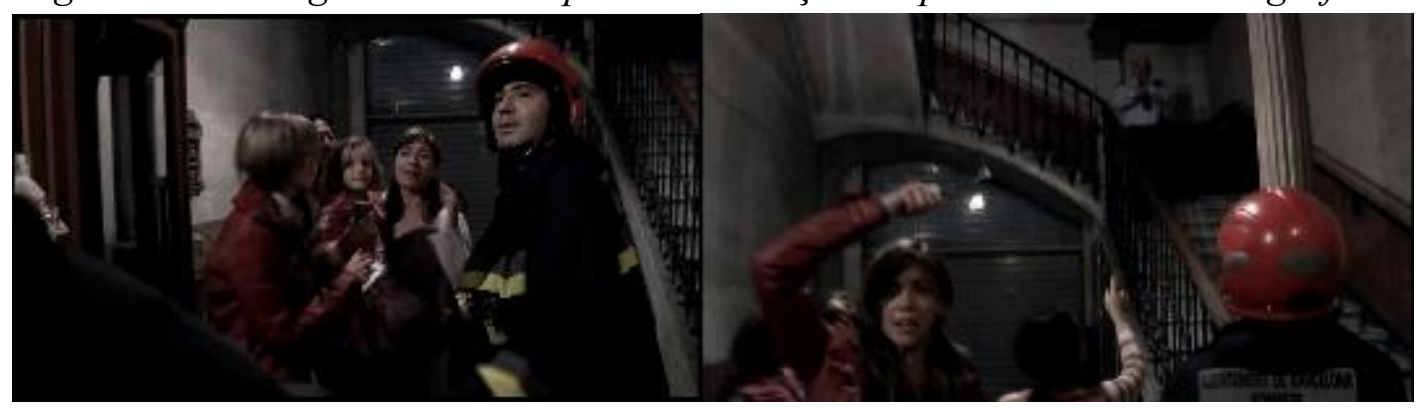

Fonte: Reprodução

Figura 10 - Pablo fica atrás do policial que comanda a subida dos bombeiros.

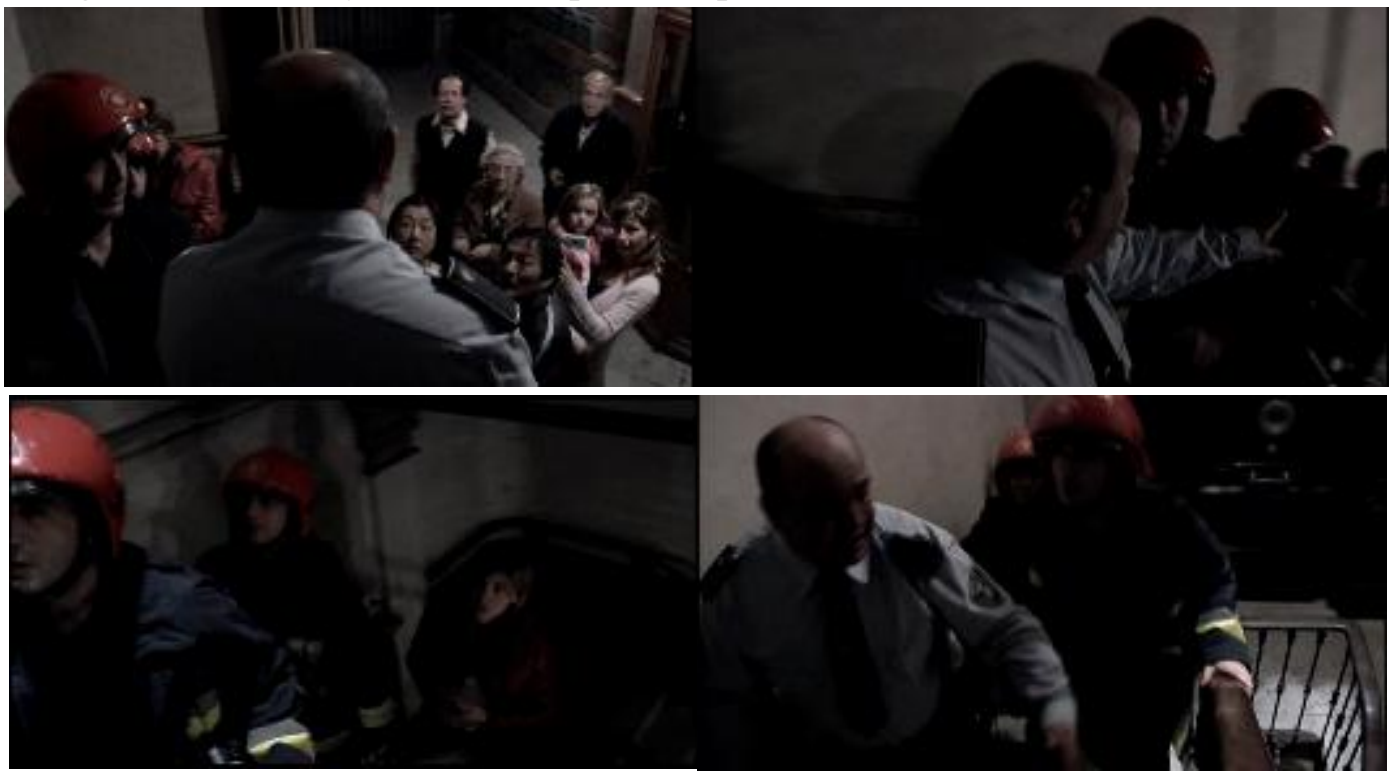




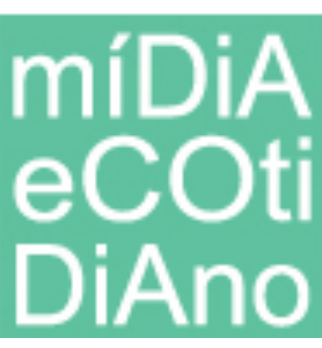

\section{PPGMC}

vif

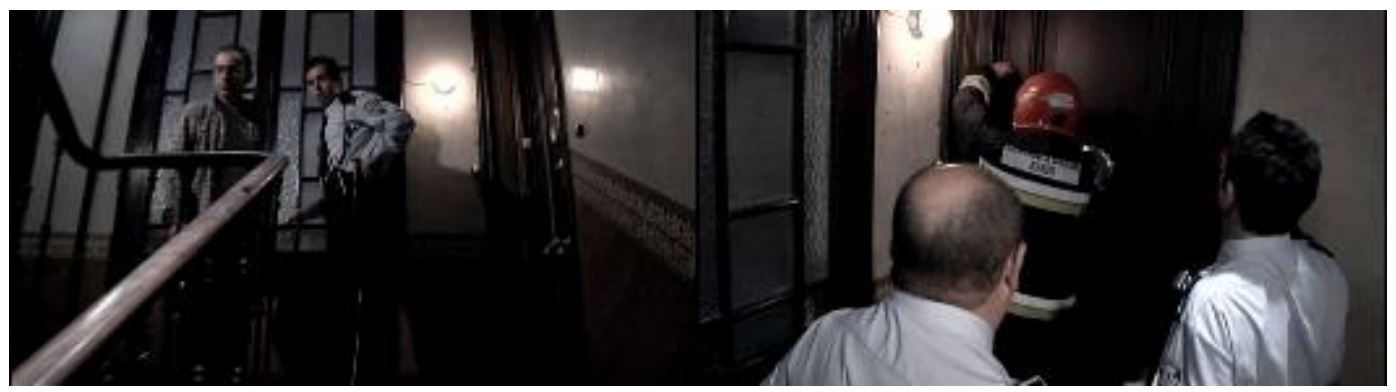

Fonte: Reprodução

É possível indicar que pelos ângulos, enquadramentos (Figura 10), em certas partes a câmera subjetiva diegética é quase que naturalizada, pois nos esquecemos dela com o manejo do artefato realizado pelo cinegrafista. Ao longo da película, Pablo nunca aparece na tela.

A aproximação de todos em direção à mulher que está com comportamento estranho segue sem mudanças bruscas. A situação só se altera quando ela ataca o policial que chega perto, o que acaba provocando a morte dele. A câmera trêmula e a fuga ocorrem pelo susto e a iminência de ser a próxima vítima. $\mathrm{O}$ choque se intensifica porque antes do ataque, Pablo deixa a câmera para baixo, a fim de despistar os policiais (Figura 11). Entretanto, o profissional segue gravando e, assim que a moradora pula no pescoço da vítima, ele acende a luz e registra tudo sem pudor, ou tentativa de auxílio. Aliás, esse mote é uma marca do found footage: a figura que filma sem parar, mesmo que isso signifique colocar a vida dos outros ou a própria em risco.

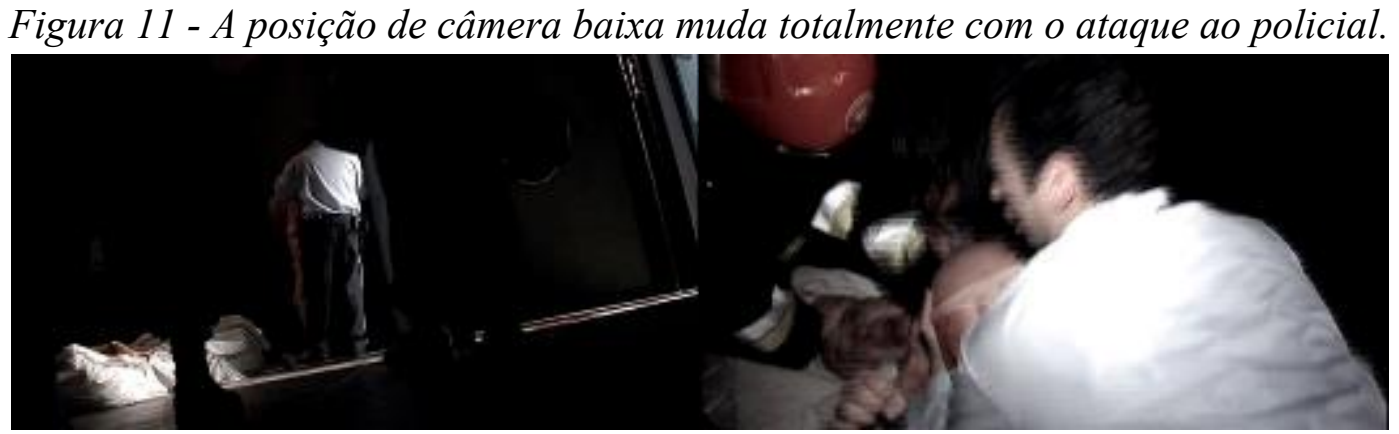

Fonte: Reprodução 
É importante frisar que o retorno ao andar térreo é o oposto da subida - a transparência das imagens quase que faz com que o público esqueça que o manejo do aparelho esteja ao cargo de um personagem, como já identificamos. Na descida, as imagens do ponto de vista de Pablo são repletas de cortes bruscos, confusão, movimentos que geram até incompreensão sobre o que está se passando. Conseguimos constatar que [Rec] joga com essas duas possibilidades de registro da imagem: a suposta "profissionalização" de quem opera o artefato e a narrativa apresentada aos solavancos, que usualmente pode confundir o espectador.

A relação corpo/superfície visual é do mesmo modo evidente em um dos episódios de $V / H / S 2$ (2013), quando um homem passa por uma cirurgia em um olho, tendo uma câmera instalada como prótese (Figura 12). A partir de então ver é sinônimo de filmar para ele, pois a lente está literalmente dentro da cabeça do narrador da história.

Figura 12 - Homem recebe câmera e chip de gravação na cabeça.

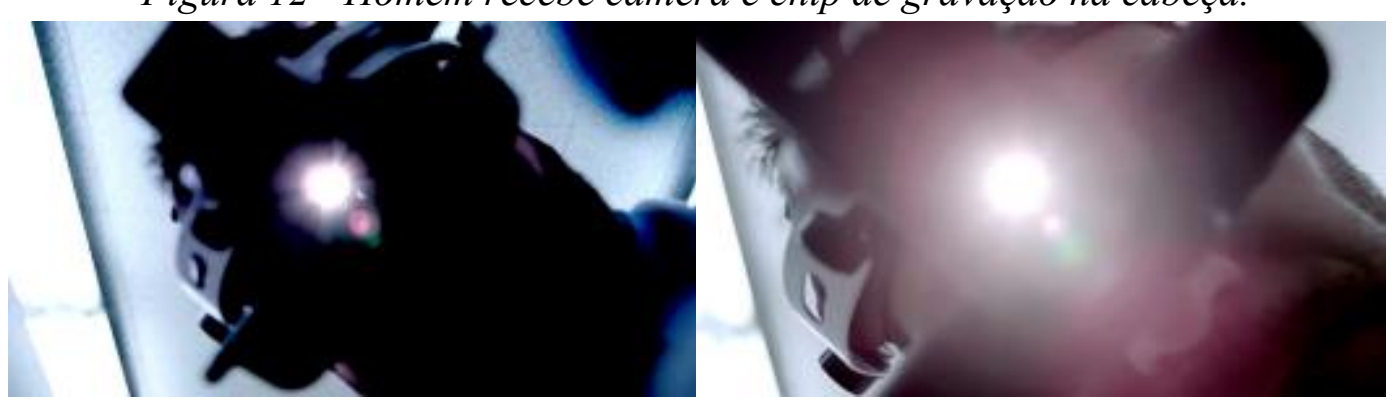




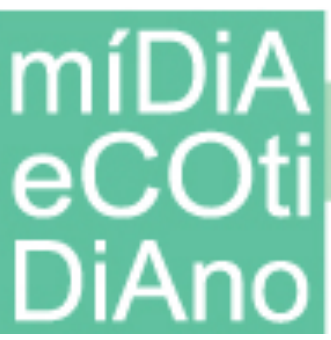

\section{PPGMC}

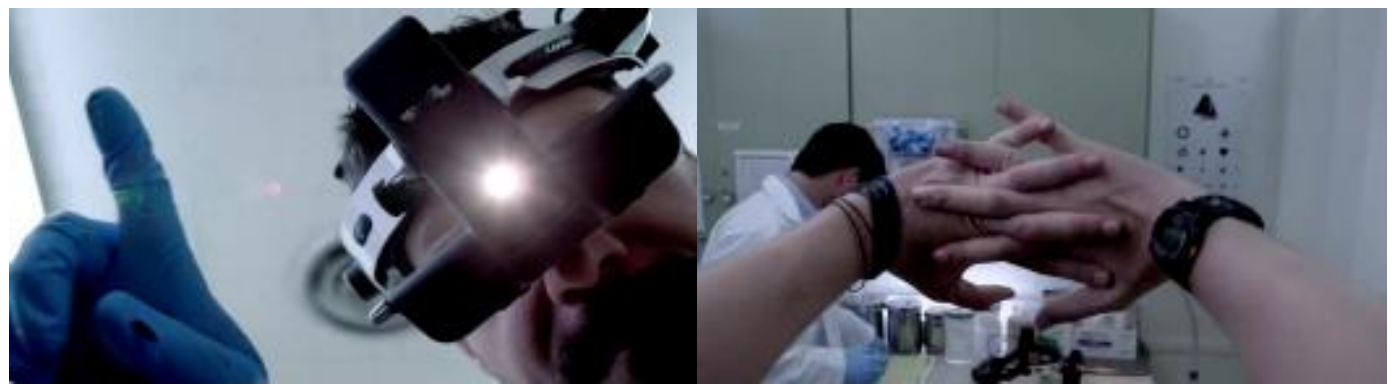

Fonte: Reprodução

Após a cirurgia, o médico deixa claro que o olho biológico está lutando contra o da câmera, mas que seria questão de tempo o hábito entre ambos. É metafórica essa abordagem a respeito da relação homem / máquina. O olho câmera ajuda a ver melhor, mas no período de testes, coisas estranhas podem ocorrer, alerta o médico. Esse "ajuste" remete ao argumento de Siegfried Zielinski (2006), de que a existência do tecnológico com o orgânico sempre se deu em tensão. Nessa trama de $V H S$ 2, percebemos inclusive as piscadas da personagem ${ }^{10}$ que viram cortes na montagem.

Ao contrário da estratégia de [Rec], enxergamos a personagem que registra a imagem e, em uma passagem diante do espelho, pode-se perceber a "câmera-prótese" dentro do órgão (Figura 13).

Figura 13 - Homem observa o olho, misto de máquina e corpo.

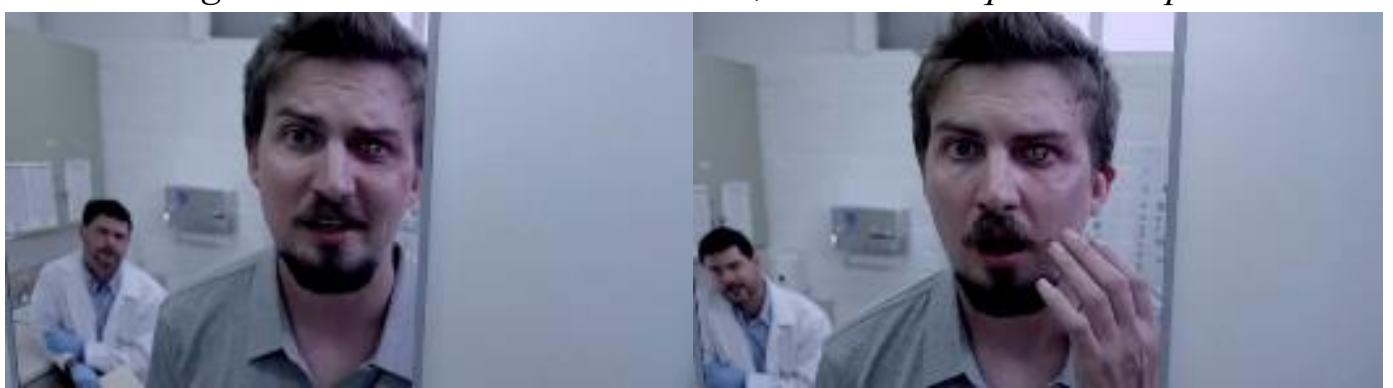

Fonte: Reprodução

O novo olho tem problemas e rupturas na imagem, acompanhadas de ruídos, enfatizando o descompasso na comunicação entre o artefato e o cérebro de quem o possui. O excerto para observação vai de 23:30 a 25:10 e traz a fuga final do personagem diante dos espíritos que aparecem em função da prótese. Ele corre desesperado da piscina, onde uma jovem desconhecida que lhe conta sobre os problemas dessas próteses (ela tem uma

\footnotetext{
${ }^{10} \mathrm{O}$ ator desse episódio de $V / H / S 2$ é Adam Wingard, que também é um dos diretores do filme. Ele lançou A Bruxa de Blair em 2016.
} 
no ouvido e escuta vozes) acabou de morrer afogada. No caminho pela casa, ele vê por diversas vezes os fantasmas (Figura 14), sempre nos ruídos visuais e sonoros do artefato, como se fossem uma interferência técnica.

Stefan Andriopoulos (2014) comenta o uso de instrumentos técnicos para suposta captação do mundo sobrenatural desde a fotografia e esse episódio de $V / H / S 2$ trata justamente dessa possibilidade. Contudo, a personagem aqui não está disposta a se comunicar com esses seres de imagem, quer apenas se livrar deles, não precisar enxergálos mais.

A correria pela casa e o encontro com os espíritos se assemelha às fugas empreendidas pelas personagens que manejam câmeras em produções found footage: desorientação, pouca iluminação, gritos, respiração ofegante, gritos, planos tremidos, cortes na imagem. A diferença aqui é que a câmera está/é a personagem.

Figura 14 - Homem corre pela casa e se depara com fantasmas.

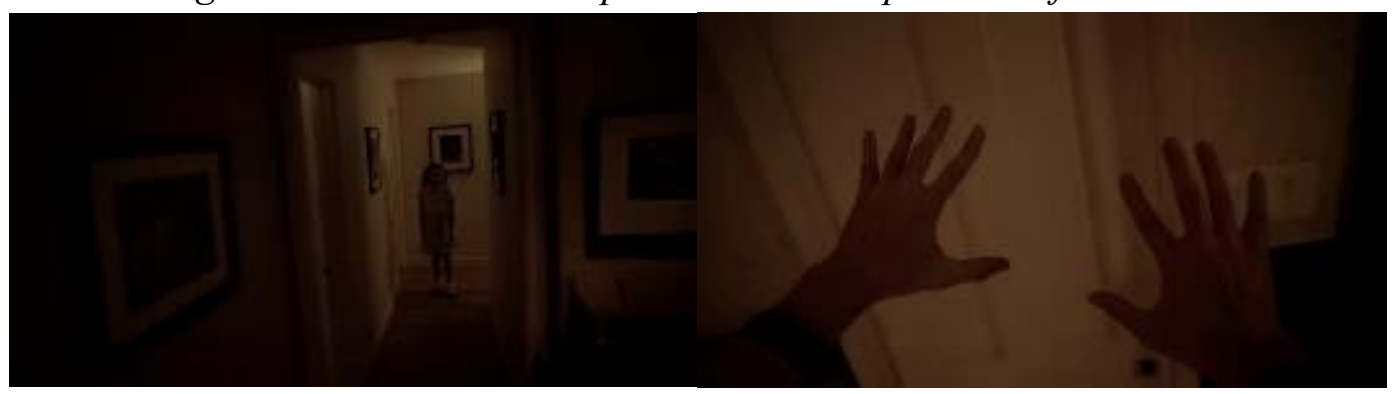

Fonte: Reprodução

Desesperado, o protagonista efetiva o ato extremo de arrancar a câmera do olho com uma navalha. A cena é de uma agonia semelhante à do clássico surrealista de Luis Buñel e Salvador Dalí, O Cão Andaluz (1929) (Figura 15).

Figura 15 - A famosa imagem do olho cortado em O Cão Andaluz. 


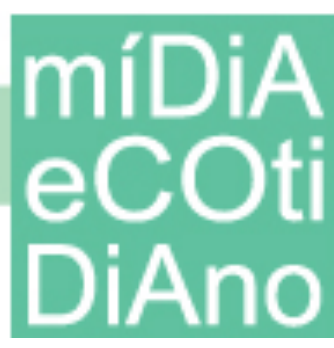

\section{PPGMC}

uff

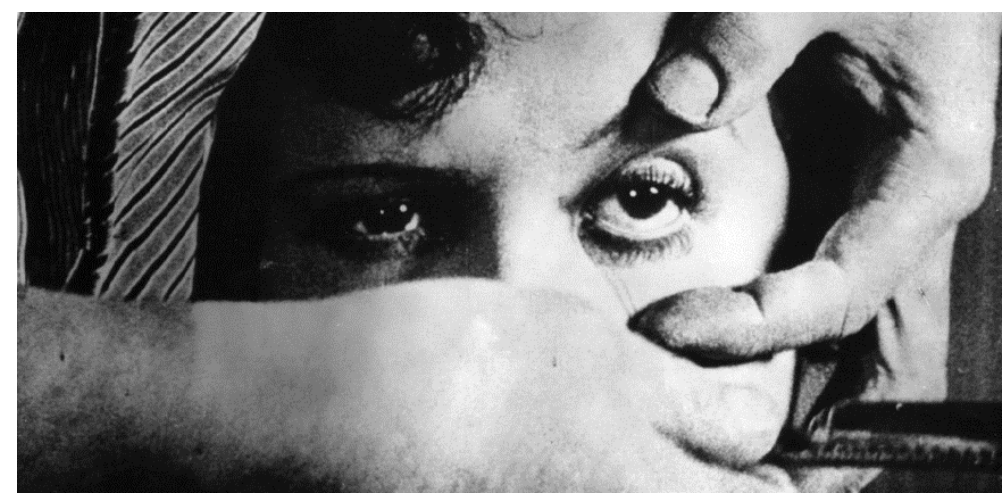

Fonte: Reprodução

No filme de 1929, o olho de um boi é cortado em substituição ao humano. No episódio de $V / H / S 2$, toma conta da tela o interior do órgão da personagem, em um misto de sangue, nervos e interferências visuais maquínicas (Figura 16).

Figura 16 - Personagem arranca a câmera do olho com uma navalha.

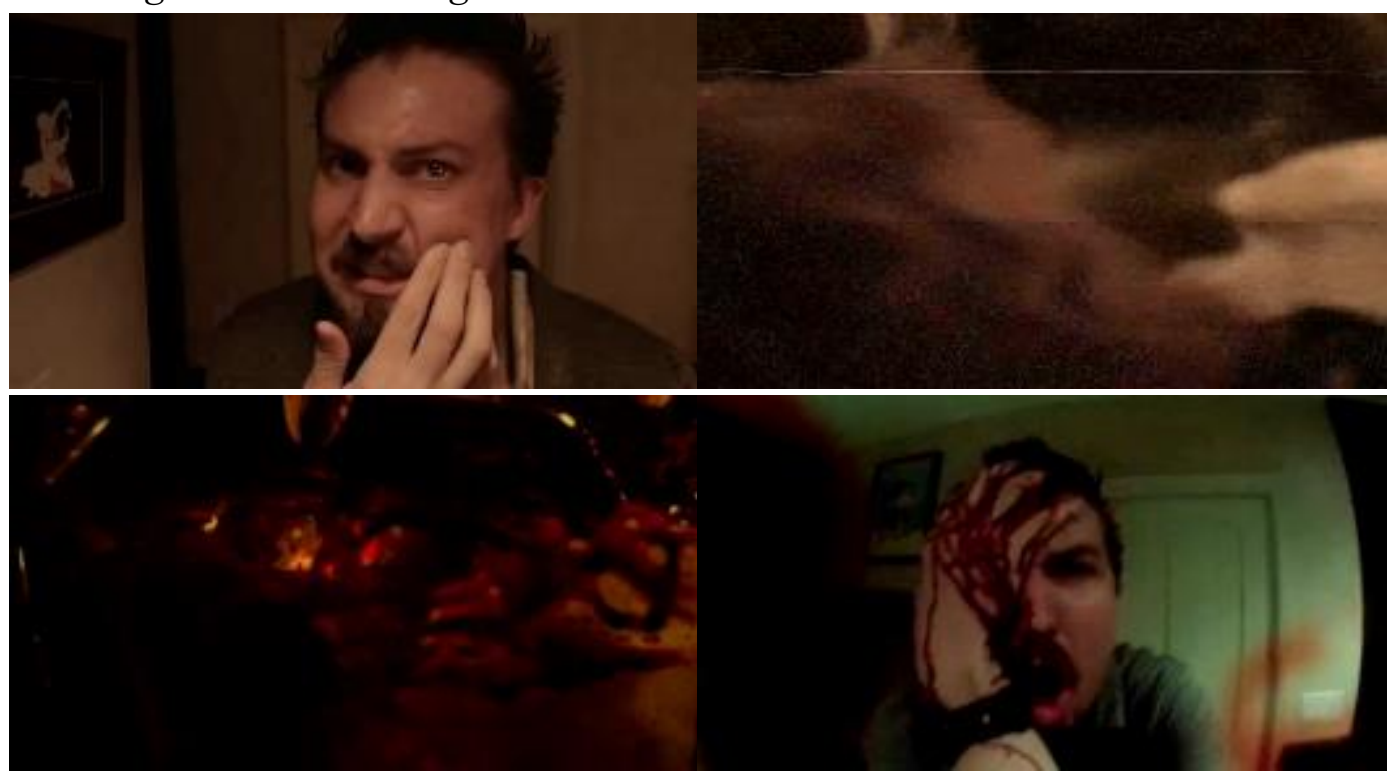

Fonte: Reprodução

Após se livrar da prótese, o homem a segura e vira para si (Figura 16), o que justifica o fato de os espectadores seguirem acompanhando a narrativa. A mutilação não o livra dos fantasmas: mesmo depois do ato, ele continua vendo os espíritos que o pegam e o obrigam a, literalmente, engolir o aparelho. Ou seja, o protagonista permanece com a 


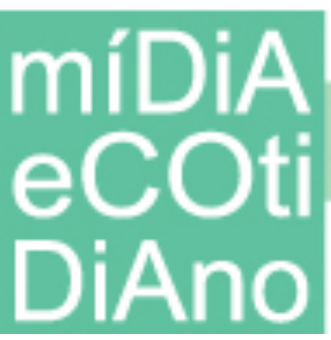

\section{PPGMC}

máquina no corpo de qualquer maneira, como se não houvesse maneira de escapar de tal condição (Figura 17).

Figura 17 - Mesmo sem a câmera no olho, os espíritos permanecem no entorno.
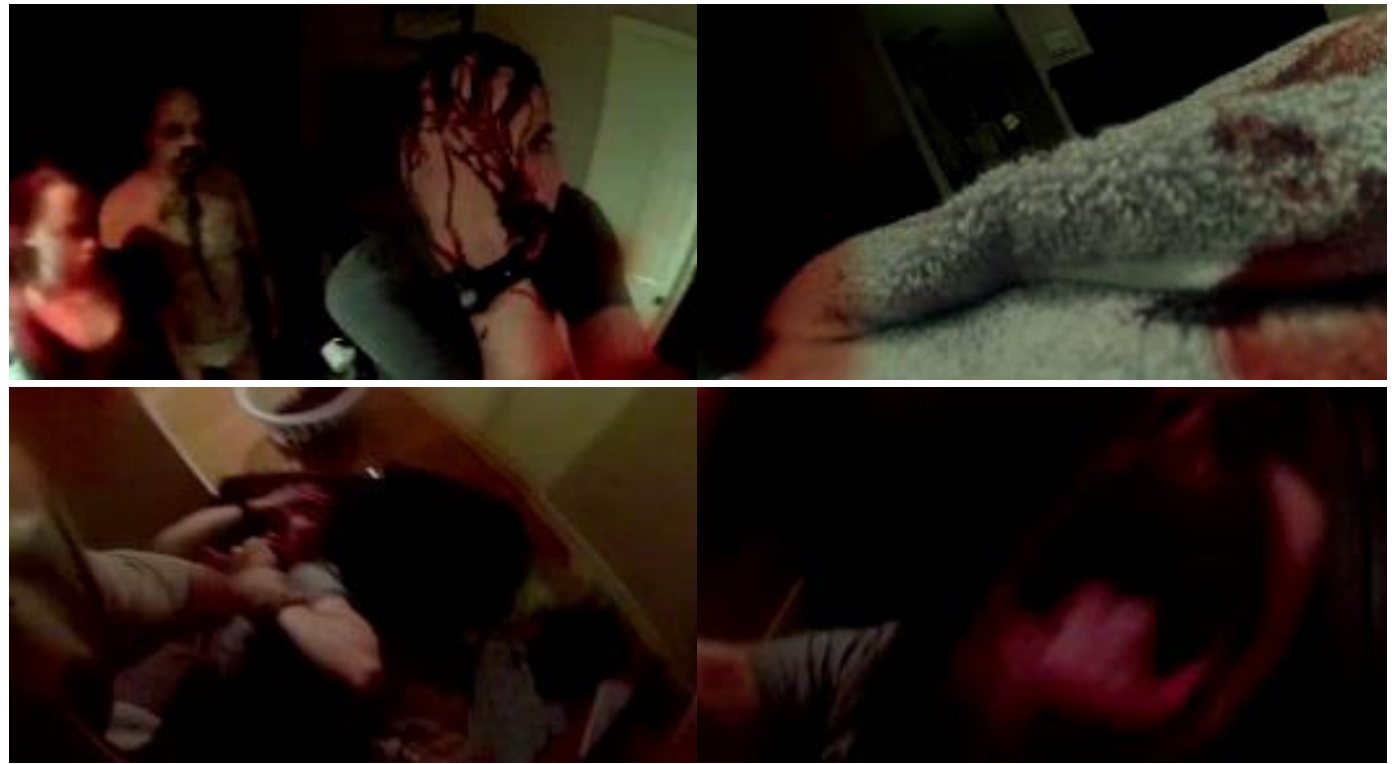

Fonte: Reprodução

A dualidade material/imaterial mantém-se nos estudos sobre imagens digitais (FLUSSER, 1985; CRARY, 2012): números, cálculos imateriais remetem a coisas materiais, imagens se constituem sem referente no mundo físico. As metáforas problematizadas por $V / H / S 2$ colocam esses impasses. Os fantasmas que assombram o protagonista não passam de imagens digitais, portanto, imateriais. Mesmo assim, essas figuras têm poder no ambiente da personagem, de certa forma algo parecido com a dimensão das imagens na nossa vida hoje.

Apesar de extirpar a fonte imagética, o homem vê a câmera retornar à força ao corpo. Os perigos, temores com a tecnologia, temática que já aparece em filmes de horror há mais tempo (FELINTO, 2008; HUTCHINGS, 2004), estão presentes nesta obra. A inovação técnica representada pela prótese é ambígua, necessita de ajustes e esse pequeno detalhe é vetor para um mundo completamente desconhecido. 


\section{CONSIDERAÇÕES FINAIS}

Ver mais, melhor, mais próximo, pelo uso de algum instrumento enxergar o que meu olho sozinho não consegue, essa questão aparece continuamente entre quem narra os processos históricos da formação do olhar (ACKER, 2017). Essa ideia possui conexão com aquilo que Heller-Nicholas identifica como "visualidade tátil" do horror found footage. O sujeito apartado da representação desde os tempos da câmara escura busca meios de tentar subverter essa condição, mesmo que de maneira simulada (CRARY, 2012). A experiência do horror necessita dessa tangibilidade para se fortalecer entre os espectadores.

A câmera subjetiva diegética talvez seja o ápice dessa abordagem no gênero nada pode ser mais tátil narrativamente falando do que possuir o instrumento de registro em mãos e no olho. Esse é um dos aspectos, juntamente com a câmera de vigilância, que mais bem caracteriza esse tipo de produção. Ter o aparelho é manifestação de poder e, mais ainda, saber que isso significa a oportunidade de deixar para a posteridade o que se passa naquele momento.

$\mathrm{O}$ ato de tudo gravar traz um paradoxo para o horror found footage, pois deter a câmera não garante qualquer possibilidade de sobrevivência. É como se as personagens cinegrafistas desses filmes já soubessem que serão apenas imagens, arquivos, dali por diante. O suposto poder, portanto, é efêmero, fluido, incerto. Isso corrobora a permanente instabilidade do sujeito observador formatado a partir da Modernidade, cristalizado após os processos de sujeição dos inúmeros aparelhos pelos quais nosso olhar tem se moldado (CRARY, 2012; 2014).

O presente texto buscou analisar o ponto de vista no horror, partindo da câmera subjetiva do slasher para a câmera subjetiva diegética do found footage, percebendo as alterações narrativas e de consumo do gênero como entretenimento a partir dessas transformações. Podemos identificar que a principal mudança está no modo como o horror contemporâneo dá a ver expressões da tecnologia que até então se mantinham em opacidade nesse tipo de produção.

O horror found footage é um fenômeno pós-sala de cinema, ainda que muitas produções circulem em grandes espaços de shopping centers e sejam lançadas em 3D. 
Para perceber isso, basta considerar que o caso do primeiro grande sucesso foi de um filme que contou com ampla campanha de marketing pela Internet: A Bruxa de Blair (1999), de Daniel Myrick e Eduardo Sánchez. Assim, ver filmes é cada vez mais uma atividade privada e individual, se está sozinho, do mesmo modo que as personagens que correm pela noite escura com uma câmera na mão. A visualidade dos games, a navegação pelas interfaces computacionais ou dispositivos móveis deixam marcas nas narrativas com esse estilo.

Se ocorre uma variedade de artefatos, do mesmo modo há diversos tipos de imagens, texturas, cores diferentes que até o desenvolvimento do found footage não haviam sido exploradas no gênero horror. A câmera subjetiva do slasher, com o predomínio do ponto de vista da ameaça, se dilui para diversos olhares quando se torna subjetiva diegética no found footage, muito em função da variação de artefatos para registro audiovisual. O caráter experimental dessas visualidades precisa ser considerado e entendido como um tensionamento das experiências estéticas dos espectadores com as obras.

Os modos de ver no cinema não são transformados por esses filmes de horror, mas eles trazem muitas camadas da formação do nosso olhar ao longo do tempo. Todos os gêneros o fazem? De certa forma sim. O que há de diferente é que o found footage faz isso de maneira deliberada, quer pensar as materialidades, o fazer cinema; busca refletir sobre o tempo dessa máquina e, fundamentalmente, a respeito daquela zona cinza que não conhecemos, não adentramos. Enfim, pensa a experiência do cinema e seus respectivos fantasmas.

\section{Referências}

ACKER, Ana Maria. O dispositivo do olhar no cinema de horror found footage. Tese de doutorado, PPGCOM, Universidade Federal do Rio Grande do Sul. Abr., 2017.

ALTMAN, Rick. Los géneros cinematográficos. Barcelona: Paidós, 2000.

ANDRIOPOULOS, Stefan. Aparições espectrais: O idealismo alemão, o romance gótico e a mídia óptica. Rio de Janeiro: Contraponto, 2014.

AUMONT, Jacques; MARIE, Michel. Dicionário teórico e crítico de cinema. Campinas, SP: Papirus, 2003.

BISKIND, Peter. Como a geração sexo, drogas e rock'n'roll salvou Hollywood. Rio de Janeiro: Intrínseca, 2009. 
BROWNE, Nick. O espectador-no-texto: a retórica de No tempo das diligências. In: RAMOS, Fernão (org.). Teoria contemporânea do cinema - volume II: Documentário e narratividade ficcional. São Paulo: Editora Senac, 2005. p. 229-249.

CÁNEPA, Laura. Medo de quê? Uma história do horror nos filmes brasileiros. 2008. 498 p. Tese de doutorado (Multimeios) - Instituto de Artes, Universidade Estadual de Campinas. Campinas, SP, 2008.

CARREIRO, Rodrigo Octávio. A Câmera diegética: clareza narrativa e legibilidade documental em falsos documentários de horror. In: XXII Encontro Anual da Compós, 2013, Bahia. Anais eletrônicos. Disponível em: $<$ http://compos.org.br/data/biblioteca_2088.pdf $>$. Acesso em março de 2017.

. Legibilidade X verossimilhança: o som no falso documentário de horror. In: XV Encontro Internacional da Sociedade Brasileira de Estudos de Cinema - SOCINE, 2011, Rio de Janeiro. Anais eletrônicos. Disponível em:

$<$ http://www.socine.org.br/anais/2011/interna.asp?cod=103>. Acesso em março de 2018.

A Câmera diegética: legibilidade narrativa e verossimilhança documental em falsos found footage de horror. Significação, v. 40, nº 40, 2013. p. 224 - 244.

Imperfeição calculada: [Rec] como paradigma do sound design em falsos

documentários de horror. E-Compós (Brasília), v. 17, p. 1-16, 2014.

O triunfo do amador: o som em $O$ Massacre da Serra Elétrica. In: XIX Estudos de

Cinema e Audiovisual Socine - Anais de Textos completos - São Paulo: Socine, 2016. p. 282 a 288.

CONRICH, Ian. Horror zone: The Cultural experience of contemporary horror cinema.

London: I.B Tauris, 2010.

CRARY, Jonathan. Téenicas do observador: visão e modernidade no século XIX. Rio de

Janeiro: Contraponto, 2012.

Naify, 2013

Suspensões da percepção: atenção, espetáculo e cultura moderna. São Paulo: Cosac

DUBOIS, Philippe. Cinema, vídeo, Godard. São Paulo: Cosac Naify, 2004.

O Fenômeno do Found Footage de Horror. In: GARCIA, Demian (org.). Cinemas de

Horror. São José dos Pinhais, PR: Editora Estronho, 2016. p. 119 - 124.

FELINTO, Erick. A Imagem Espectral: Comunicação, Cinema e Fantasmagoria Tecnológica. Cotia, SP: Ateliê Editorial, 2008.

HELLER-NICHOLAS, Alexandra. Found footage horror films: fear and the appearance of reality. Jefferson, NC: McFarland, 2014.

HUTCHINGS, Peter. The Horror film. London: Routledge, 2004.

MANNONI, Laurent. A grande arte da luz e da sombra: arqueologia do cinema. São Paulo: SENAC São Paulo, 2003.

SCONCE, Jeffrey. Haunted Media: Electronic Presence from Telegraphy to Television. Durham: Duke University Press, 2000.

WOOD, Robin. An Introduction to the American Horror Film: I. Repression, the Other, the Monster, American Nightmare. Toronto: Festival of Festivals, 1979.

Hollywood: from Vietnam to Reagan.... and beyond. New York: Columbia University Press books, 2003.

ZIELINSKI, Siegfried. Arqueologia da mídia: em busca do tempo remoto das técnicas do ver e do ouvir. São Paulo: Annablume, 2006. 